\title{
Identification of single nucleotide polymorphisms in the bovine Toll-like receptor 1 gene and association with health traits in cattle
}

\author{
Christopher D Russell ${ }^{1,2}$, Stephanie Widdison ${ }^{1,2}$, James A Leigh ${ }^{2}$ and Tracey J Coffey ${ }^{1,2^{*}}$
}

\begin{abstract}
Bovine mastitis remains the most common and costly disease of dairy cattle worldwide. A complementary control measure to herd hygiene and vaccine development would be to selectively breed cattle with greater resistance to mammary infection. Toll-like receptor 1 (TLR1) has an integral role for the initiation and regulation of the immune response to microbial pathogens, and has been linked to numerous inflammatory diseases. The objective of this study was to investigate whether single nucleotide polymorphisms (SNPS) within the bovine TLR1 gene (boTLR1) are associated with clinical mastitis (CM).

Selected boTLR1 SNPs were analysed within a Holstein Friesian herd. Significant associations were found for the tagging SNP -79 T> G and the $3^{\prime} U T R$ SNP $+2463 C>T$. We observed favourable linkage of reduced CM with increased milk fat and protein, indicating selection for these markers would not be detrimental to milk quality. Furthermore, we present evidence that some of these boTLR1 SNPs underpin functional variation in bovine TLR1. Animals with the GG genotype (from the tag SNP -79 T > G) had significantly lower boTLR1 expression in milk somatic cells when compared with $T$ T or TG animals. In addition, stimulation of leucocytes from GG animals with the TLR1-ligand Pam3csk4 resulted in significantly lower levels of CXCL8 mRNA and protein.

SNPs in boTLR1 were significantly associated with CM. In addition we have identified a bovine population with impaired boTLR1 expression and function. This may have additional implications for animal health and warrants further investigation to determine the suitability of identified SNPs as markers for disease susceptibility.
\end{abstract}

\section{Introduction}

Bovine mastitis is an inflammatory udder disease of great economic importance to the dairy industry. Mastitis is caused mainly by intramammary bacterial infection hence effective disease control measures rely upon farm management practices to limit the duration of infection and to restrict contagious spread of pathogens through the herd. As a result of these control measures opportunistic pathogens such as Escherichia coli and Streptococcus uberis predominate, and are now the leading cause of mastitis in the UK and common causes of mastitis worldwide [1]. Vaccination programmes may be required to further control mastitis [2], however no effective vaccines are currently available. An additional long term and complementary strategy is the genetic

\footnotetext{
* Correspondence: tracey.coffey@nottingham.ac.uk

'Bovine Genomics Group, Institute for Animal Health, Compton, Berkshire, RG20 7NN, UK

Full list of author information is available at the end of the article
}

selection of cattle that are less prone to mastitis. A lack of phenotypic data on clinical mastitis (CM) limits many breeding programmes, which select on the basis of a lowered somatic cell count (SCC) as a surrogate of CM [3]. The correlation between basal SCC and CM continues to be questioned $[4,5]$ and the elucidation of more accurate genetic risk factors for $\mathrm{CM}$ is required. The identification of single nucleotide polymorphisms (SNPs) within genes involved with the mammary innate immune response are receiving particular interest as DNA markers for CM susceptibility [6-9].

The innate immune system provides an early defence to microbial pathogens [10] and involves cell surface proteins from the Toll-like receptor (TLR) family. TLRs are a structurally conserved type I membrane-bound class of pathogen recognition receptor (PRR), that can differentiate between an array of pathogen-associated molecular patterns (PAMPs) [11,12]. Functional expression of TLRs on resident mammary immune cells and
C Biomed Central

() 2012 Russell et al; licensee BioMed Central Ltd. This is an Open Access article distributed under the terms of the Creative Commons Attribution License (http://creativecommons.org/licenses/by/2.0), which permits unrestricted use, distribution, and reproduction in any medium, provided the original work is properly cited. 
epithelia has been shown to be important in the initiation and control of innate immune responses towards mastitis-causing bacteria [13-16]. Ten functional bovine (bo) TLRs have been characterised (Coffey et al. unpublished) [17], revealing close identity to their human orthologues [18]. Each individual TLR possesses its own ligand recognition repertoire, and upon stimulation activate internal adaptor proteins to initiate signalling for the NF $\kappa \mathrm{B}$-mediated production of pro-inflammatory cytokines including the chemokine CXCL8 [19]. During mastitis, CXCL8 production increases rapidly [20] providing a potent chemotactic gradient to promote neutrophil movement into the mammary gland, a vital early defence mechanism against infection.

The presence of SNPs within mammalian TLRs has been shown to predispose susceptibility to a number of inflammatory diseases [21-23]. TLR1 variants have been postulated to underlie the altered immune responses to a wide spectrum of bacterial pathogens. In humans, a non-synonymous TLR1 SNP located within the transmembrane domain, which had an impact on TLR1 trafficking, $\mathrm{NF} \kappa \mathrm{B}$ activity and cytokine output, was found to have strong associations with susceptibility to and progression of infection by Gram positive bacteria and Mycobacterium leprae [24,25]. Polymorphisms affecting boTLR1 may therefore predispose excessive or poor immune responses to pathogens and hence could confer an increased risk of mammary infection.

Mammalian TLR1 is a member of a unique TLR subfamily that includes TLR6 and TLR10. All have the ability to form heterodimers with TLR 2 to expand the repertoire of recognised ligands. TLR1/TLR2 complexes mediate cellular responses to natural triacylated lipoprotein structures [26,27], which are cell wall constituents of Gram-positive and Gram-negative bacteria [28]. TLR6/TLR2 complexes expand ligand recognition to diacylated lipoproteins, although in cattle the boTLR1/ TLR2 complex may be further activated by diacylated lipoproteins [29]. Whilst more investigation is required to uncover their function, TLR10/TLR2 complexes may extend recognition of TLR1 agonists via an unknown signalling mechanism [30]. Phylogenetic analysis of boTLR1, 6 and 10 reveals common ancestry with all three genes located in tandem to form a $\sim 69 \mathrm{~kb} T L R 6-$ TLR1-TLR10 gene cluster on Bos taurus chromosome 6 (bta6) [31]. Genome-wide quantitative trait locus (QTL) studies reveal the boTLR6-TLR1-TLR10 gene cluster to be situated within a dense QTL region for a number of milk production traits and CM [32,33]. Furthermore, boTLR1 has been highlighted as a strong candidate for underlying QTL regions for disease resistance such as mastitis [34].

Despite strong QTL evidence, associative studies between boTLR1 and mastitis are limited. The boTLR1 coding sequence (CDS) is highly polymorphic, containing many SNPs across several cattle breeds [35]. Four SNPs within the CDS of boTLR1 were identified in Holstein cows [36], but only one non-synonymous SNP, located within the transmembrane domain, was reported to result in highly significant differences in SCC between all genotype populations. More investigation is required to verify such studies, and to establish associations with novel boTLR1 SNPs/haplotypes. More importantly, the ability to use data indicating actual CM incidence, rather than a surrogate such as SCC, and associate this with specific genetic markers has the potential to yield more accurate information.

We report the identification of boTLR1 SNPs within coding and non-coding regions, and their potential as genetic markers for mastitis. We further demonstrate evidence of variable receptor response between defined boTLR1 SNP genotypes.

\section{Materials and methods}

\section{Ethics statement}

All experiments conformed to local and national guidelines on the use of experimental animals.

\section{Sample population}

The herd of Holstein Friesian cows used during this project (Mayfield Dairy, Institute for Animal Health, Compton, UK) contributes to the National Milk Records (NMR) [37] which submits production records for each animal to a database accessed through the InterHerd software programme (University of Reading/PAN Livestock services team, UK). This, along with health data held locally, provided comprehensive information for each cow within the herd. All animal data were recorded within the years 2001-2010, during which, the mean CM incidence for the milking herd was 60 cases per 100 cows per year.

\section{Isolation and extraction of genomic DNA from milk somatic cells}

Milk samples $(50 \mathrm{~mL})$ were held on ice prior to centrifugation (3000 $\mathrm{g}$; $5 \mathrm{~min}$; $4^{\circ} \mathrm{C}$ ). Supernatants were carefully removed along with any residual fat layer. Remaining casein micelles were removed using an adaptation of a procedure devised previously [38]. In brief, cell pellets were re-suspended in $1.5 \mathrm{~mL}$ PBS/ EDTA solution ( $1 \mathrm{~mL}$ PBS, $300 \mu \mathrm{L} 0.5 \mathrm{M}$ EDTA and $200 \mu \mathrm{L}$ TE buffer - 10 mM-Tris-HCl-1 EDTA pH 7.6), mixed well and allowed to stand at room temperature (RT) for $10 \mathrm{~min}$. Cells were re-pelleted by centrifugation (7000 g; $1 \mathrm{~min}$; RT), the supernatant discarded and cells re-suspended in $1.5 \mathrm{~mL}$ of TE buffer. Cells were pelleted again $(7000 \mathrm{~g} ; 1 \mathrm{~min})$ and resuspended in $200 \mu \mathrm{L}$ PBS. 
Milk somatic cells were processed using the Qiagen DNeasy blood and tissue kit for genomic DNA isolation (Qiagen Ltd, Sussex, UK). Briefly, $20 \mu \mathrm{L}$ proteinase K solution (Qiagen Ltd.) was added to resuspended cells and mixed well before being incubated overnight at $4{ }^{\circ} \mathrm{C}$. To ensure RNA-free genomic DNA, $4 \mu \mathrm{L}$ RNase A (100 $\mathrm{mg} / \mathrm{mL}$ ) was added following overnight incubation and samples left for $2 \mathrm{~min}$ at RT. DNA was extracted using the column protocol according to manufacturer's instructions (Qiagen Ltd). The quantity and quality of DNA was analysed using a NanoDrop 8000 spectrophotometer (Thermo Scientific, USA) and agarose gel electrophoresis.

\section{Identification and sequencing of sample population for boTLR1 SNPs}

BoTLR1-specific primers for PCR amplification of coding and non-coding genomic regions were designed based on the Bos taurus genome annotation build: Btau_4.0 (NC_007304.4). Sequencing of PCR amplicons from a DNA pool comprising animals with high (greater than six lifetime CM cases) or no mastitis case histories was initially chosen as a method of accelerating detection of disease-associated SNPs. Selected animals were unrelated and shared similar ages and lactation histories. PCR was performed using DreamTaq ${ }^{\mathrm{TM}}$ DNA polymerase (Fermentas UK, York, UK) following the manufacturer's protocol. Sequencing of purified PCR products was carried out using BigDye Terminator v3.1 Cycle Sequencing Kit (Applied Biosystems, Warrington, UK). Samples were sequenced by capillary electrophoresis on an ABI PRISM 310 Genetic Analyser (Applied Biosystems), and analysed using the Sequencher ${ }^{\mathrm{TM}}$ package version 4.1.4 (Gene Codes Corporation, Ann Arbor, MI, USA). All primers (Additional file 1) were designed using Primer3 software [39] and synthesised by Sigma-Genosys Ltd. (Haverhill, UK). All boTLR1 SNP offsets are given relative to their position (bp) from the A nucleotide of the ATG codon. Sequencing of PCR amplicons was extensively used to genotype the herd population.

\section{Restriction fragment length polymorphism (RFLP) - PCR analysis}

In addition to sequencing of PCR amplicons, SNPs +798 $\mathrm{C}>\mathrm{T}$ and $+1762 \mathrm{~A}>\mathrm{G}$ were genotyped using RFLP analysis of PCR products; whereby restriction enzyme MboII cuts in the presence of the C allele for SNP +798 $\mathrm{C}>\mathrm{T}$, and restriction enzyme BclI cuts only in the presence of the A allele (Isoleucine) for the non-synonymous SNP +1762A > G; as described previously [36]. Restriction digests were performed in a final volume of $20 \mu \mathrm{L}$ containing $10 \mu \mathrm{L}$ PCR product and $2 \mathrm{U}$ of appropriate restriction enzyme. Digests were incubated at the recommended temperature for $2 \mathrm{~h}$, with a subsequent heat inactivation of enzyme at $65^{\circ} \mathrm{C}$ for $20 \mathrm{~min}$. Homozygous and heterozygous samples, confirmed by sequencing, were included as controls.

\section{Identifying associations between SNPs and clinical mastitis and milk quality}

Identified SNPs were correlated to health or milk productivity trait data available through the InterHerd software programme and NMR data. These included CM case histories, milk SCC, mean 305 d milk yields and mean milk protein/fat concentrations. All Animal data were recorded within and up to, the first three lactations only. Median SCC was transformed logarithmically as NEWSCC = LOG2 (SCC/100 000) + 3. This model accounts for the skewness of data distribution as used previously [3]. CM was analysed for presence or absence of cases across the entire milking tenure of their first three lactations. Mean incidence of CM is presented as cases per cow per year ([total number of cases/total number of milking days]*365) within the first three lactations. CM was defined as an individual clinically apparent event, coupled with a rise in milk SCC and/or isolation of pathogen, recorded on a single day within any/all quarters during a lactation period. Repeated cases within the same quarter were noted but only regarded as a new case after seven days return to milking.

\section{Statistical analysis}

Genotypic frequencies were tested for deviation from Hardy-Weinberg equilibrium according to $\mathrm{Chi}^{\wedge} 2$ test and level of significance at 1 degree of freedom. Haplotypes and linkage disequilibrium (LD) scores (based on the $r^{2}$ statistic), were analysed using the Haploview programme [40]. Owing to substantial positive skewness (due to zero values) of data distribution, mean CM rate was transformed: NEWCM = LOG10 $(\mathrm{CM}+1)$. A genotypic model was used for separate genotype pair-wise comparisons. One-way analysis of variance (ANOVA) and Tukey's multiple comparisons for CM rate, milking traits and functional data means, were performed using Prism ${ }^{\circledR} 5.04$ software (Graph Pad Software, Inc, CA, USA). Presence of any CM event across all lactations $(\mathrm{CM}$ recorded $=1$, no recorded $\mathrm{CM}=0$ ) between genotypes were pair-wise tested for significance by a $\mathrm{Chi}^{\wedge} 2$ odds ratio test using Minitab ${ }^{\circledR} 16$ software (Minitab Statistical Software, Inc, PA, USA). Calculation of Pearson correlation coefficients between factors and analysis of CM response in a General linear model (GLM) was performed using Minitab ${ }^{\circledR} 16$ software.

\section{Isolation of polymorphonuclear leukocytes from bovine blood}

For stimulation assays, polymorphonuclear leukocytes (PMNs) were isolated from $50 \mathrm{~mL}$ blood samples of healthy, age-matched, genotyped cattle that had recorded 
no intramammary infection in the two weeks prior to sample collection. Briefly, blood was collected into EDTA (final concentration of $\sim 1.5 \% \mathrm{w} / \mathrm{v}$ ), centrifuged at RT (15 min; $1000 \mathrm{~g}$ ) and the plasma and buffy coat phases carefully removed. For every $2.5 \mathrm{~g}$ of lower blood phase, 10 $\mathrm{mL}$ of $\mathrm{H}_{2} \mathrm{O}$ was added. The mixture was agitated and left for $40 \mathrm{~s}$ before adding half the water volume of $\mathrm{NaCl} / \mathrm{PO}_{4}$ reagent $\left(2.7 \% \mathrm{NaCl} / \mathrm{PO}_{4}\right.$ reagent: $2.7 \mathrm{~g} \mathrm{NaCl}$ into $10 \mathrm{~mL}$ $0.132 \mathrm{M}$ phosphate buffer $\left(18.74 \mathrm{~g} \mathrm{Na}_{2} \mathrm{HPO}_{4}\right.$ and $17.96 \mathrm{~g}$ $\mathrm{KH}_{2} \mathrm{PO}_{4}$ into $1 \mathrm{~L} \mathrm{H}_{2} \mathrm{O}, \mathrm{pH}$ 6.8) and made up to $100 \mathrm{~mL}$ with $\mathrm{H} 2 \mathrm{O}$ ) to restore the isotonic strength. PMNs were pelleted by centrifugation $(125 \mathrm{~g} ; 10 \mathrm{~min}$; RT), the supernatant discarded and the cells re-suspended in $1.5 \mathrm{~mL}$ of PBS. This was repeated twice to wash the cells. Typically 1 $\times 10^{8}$ PMN cells were obtained per $50 \mathrm{~mL}$ sample. FACS analysis of polymorphic PMN samples suggested little difference in cell populations and purity obtained from the different genotypes.

Isolated PMNs were seeded to $1 \times 10^{6} / 1 \mathrm{~mL}$ in RPMI $1640+$ GlutaMAX ${ }^{\mathrm{TM}^{\mathrm{M}}}$ with $10 \%$ foetal calf serum (FCS) (both Invitrogen Ltd. UK) and 100 units $\mathrm{mL}^{-1} / 100 \mu \mathrm{g}$ $\mathrm{mL}^{-1}$ Penicillin/Streptomycin (Sigma, St Louis, MO, USA). Prior to stimulation, seeded cells were incubated at $37^{\circ} \mathrm{C}$, in $5 \% \mathrm{CO}_{2}$ for approximately $18 \mathrm{~h}$ in 24 well tissue culture plates.

\section{Stimulation of PMNs with TLR ligands}

All TLR ligands (InvivoGen, San Diego, CA, USA) were reconstituted in sterile endotoxinfree water according to the manufacturers' instructions, to a concentration of 1 $\mathrm{mg} \mathrm{mL}^{-1}$, and stored at $20^{\circ} \mathrm{C}$. The synthetic TLR1-specific ligand PAM3 was added to the cells in $100 \mu \mathrm{L}$ of culture media, at final concentrations of $100 \mathrm{ng} / \mathrm{mL}, 250$ $\mathrm{ng} / \mathrm{mL}$ and $500 \mathrm{ng} / \mathrm{mL}$. A media control (containing no ligand) was used. LPS (100 ng/mL) was used as a nonTLR1 stimulant. Stimulated cells $(4 \mathrm{~h}$ and $8 \mathrm{~h}$ post stimulation) were lysed and total RNA extracted. Supernatants were taken $24 \mathrm{~h}$ post stimulation for detection of cytokine production by ELISA.

\section{RNA isolation and CDNA synthesis}

Pelleted cell samples were lysed in RLT buffer for total RNA extraction using the RNeasy mini kit (Qiagen Ltd) according to manufacturer's instructions. Samples were DNase treated (DNAfree, Ambion, Austin, TX, USA) and analysed for quantity and quality. Total RNA was used for cDNA synthesis using SuperScript II Reverse Transcriptase (Invitrogen Ltd. UK) using the recommended protocol. Quantification of cDNA was carried out using the NanoDrop 8000 spectrophotometer.

\section{Q-PCR analysis}

Quantitative PCR (Q-PCR) was performed with the ABI Prism 7500 FAST Sequence Detection System (Applied
Biosystems) using FAST Universal Mastermix (Applied Biosystems) according to the manufacturer's protocol. Taqman ${ }^{\circledR}$ probe and primers for GAPDH, CXCL8 and $B c l 2 A 1$ have been designed previously [41-43]. Taqman ${ }^{\circledR}$ probe and primers for boTLR1 were designed from sequenced templates, avoiding any SNPs, using the Primer3 software [39] (Forward: 5'-GCA CCA CAG TGA GTC TGG AA -3', Reverse: 5'GTA CGC CAA ACC AAC TGG AG -3', Probe: 5'-TGT GTG CTT GAT GAT AAT GGG TGT CCT -3'). All primers and probes were synthesised by Sigma-Genosys Ltd. and Eurogentec Ltd. (Romsey, UK) respectively. Probes were labelled at the 5 ' end with the reporter dye FAM (6-carboxyfluorescein) and at the 3' end with the quencher dye TAMRA (6-carboxytetramethylrhodamine). $100 \mathrm{ng}$ of cDNA template from each animal were tested in triplicate and quantified by comparison with a standard curve from plasmid DNA of known copy number. Relative target gene expression was then calculated by normalising to the mean expression levels of the housekeeping genes glyceraldehyde-3-phosphate dehydrogenase (GAPDH) and ribosomal protein, large, P2 (RPLP2). Analysis was performed using Microsoft ${ }^{\circledR}$ Excel 2008 (Microsoft Co., Redmond, WA, USA) and Prism ${ }^{\circledR} 5.04$ software. Differences between groups were assessed by one-way analysis of variance (ANOVA) and Tukey's multiple comparisons.

\section{ELISA}

Levels of CXCL8 were determined by luminescent ELISA, using a pair of commercial human IL-8 specific antibodies (R\&D Systems, Oxon, UK) according to a modified luminescence-based ELISA described previously [44]. Samples were tested in triplicate, with recombinant bovine CXCL8 (Kingfisher Biotech, Inc., MN, USA) as the standard. Levels of bovine IL- 6 were determined using a commercial TMB ELISA kit according to the manufacturer's protocol (Thermo Fisher Scientific, Inc. USA). Differences between groups were assessed by one-way analysis of variance (ANOVA) and Tukey's multiple comparisons.

\section{Results}

\section{Characterisation of boTLR1 SNPs}

The genomic organisation of boTLR1 was confirmed using internal cDNA sequencing, and analysis of EST data submitted to the NCBI database. As described previously [31], the full length boTLR1 mRNA transcript comprises five exons and four introns. The CDS for full length boTLR1; a 2379 bp transcript corresponding to a 793 aa chain [45], is located within exon 5. Sequencing of boTLR1 within a Holstein Friesian herd $(n=246)$ revealed eleven SNPs; five of which are novel (Table 1 ). Eight of the eleven SNPs were exonic, six were located 
Table 1 Identified SNPs within boTLR1 from Holstein Friesians.

\begin{tabular}{|c|c|c|c|c|c|c|}
\hline SNP & Genomic (bta6) position & Amino acid position & Amino acid & Restriction site presence & Previously reported & dbSNP ID \\
\hline$-1205 \underline{A}>\mathrm{G}$ & 60440366 & - & - & - & No & - \\
\hline-1151 I $>A$ & 60440312 & - & - & - & No & - \\
\hline$-79 I>G$ & 60439240 & - & - & - & No & - \\
\hline$+798 \underline{C}>T$ & 60438363 & 266 & Phe-Phe & Mboll & Yes $^{1}$ & ss73689409 \\
\hline$+1641 \mathrm{~A}>\mathrm{C}$ & 60437520 & 547 & Ser-Ser & Bst $X-1$ & Yes $^{2}$ & ss73689413 \\
\hline$+1716 \underline{G}>A$ & 60437445 & 572 & Lys-Lys & Bsi Y & $\mathrm{Yes}^{2}$ & ss73689414 \\
\hline$+1762 \underline{A}>G$ & 60437324 & 587 & Ile-Val & $\mathrm{BCl} \mathrm{I}$ & Yes $^{2}$ & ss73689415 \\
\hline$+2100 \underline{C}>T$ & 60436989 & 700 & Phe-Phe & - & $\mathrm{Yes}^{2}$ & ss73689417 \\
\hline$+2103 \mathrm{I}>\mathrm{C}$ & 60436986 & 701 & Val-Val & $\mathrm{BsmAl}$ & Yes $^{2}$ & ss73689418 \\
\hline$+2463 \underline{C}>T$ & 60436698 & - & - & Msll & No & - \\
\hline$+2731 \mathrm{~A}>\mathrm{G}$ & 60436430 & - & - & - & No & - \\
\hline
\end{tabular}

Abbreviations: bta6 $=$ Bos taurus chromosome $6, \mathrm{dbSNP}=$ Single-Nucleotide Polymorphism Database [46]. All boTLR1 sequences were aligned with the published Btau_4.0 sequence NC_007304.4 (underlined allele denotes the published sequence). Light shading - synonymous coding SNPs, dark shading -non-synonymous coding SNP. All boTLR1 SNP offsets are given relative to their position (bp) from the A nucleotide of the first ATG codon. ${ }^{1}$ [31], ${ }^{2}$ [35].

in the CDS, of which only one was a non-synonymous change $(+1762 \mathrm{~A}>\mathrm{G}$, Iso $>\mathrm{Val})$ positioned within the transmembrane domain, while the remaining two were located in the non-coding 3'UTR. The three non-exonic SNPs were identified within the introns of the 5' UTR (Figure 1).

\section{Genotypes and allelic frequencies}

Five boTLR1 SNPs: $-79 \mathrm{~T}>\mathrm{G},+798 \mathrm{C}>\mathrm{T},+1762 \mathrm{~A}>$ $\mathrm{G},+2463 \mathrm{C}>\mathrm{T}$, and $+2731 \mathrm{~A}>\mathrm{G}$ (Figure 1) were detected within the herd $(n=156,246,125,225$ and 232 respectively). The genotypic and allelic frequencies for each SNP are similar, with heterozygotes the most abundant genotypes (Table 2). All SNPs were found to be in agreement with Hardy-Weinberg equilibrium. The three SNPs $-79 \mathrm{~T}>\mathrm{G},+798 \mathrm{C}>\mathrm{T}$, and $+2731 \mathrm{~A}>\mathrm{G}$ were in strong linkage disequilibrium $(\mathrm{LD}=>0.9)$ (Figure 2 ) and as a result only the SNP $-79 \mathrm{~T}>\mathrm{G}$ was used for association analysis. LD between the tagging SNP -79 $\mathrm{T}>\mathrm{G}$ and the nonsynonymous $+1762 \mathrm{~A}>\mathrm{G}$ was moderate $(\mathrm{LD}=\sim 0.8)$. LD between SNPs $-79 \mathrm{~T}>\mathrm{G}$ and $+2463 \mathrm{C}>\mathrm{T}$ was lower. The lowest LD was observed between SNPs $+1762 \mathrm{~A}>\mathrm{G}$ and $+2463 \mathrm{C}>\mathrm{T}$ (Figure 2). Consequently, analysis of association with traits for SNPs $-79 \mathrm{~T}>\mathrm{G},+1762 \mathrm{~A}>\mathrm{G}$ and $+2463 \mathrm{C}>\mathrm{T}$ was performed individually. Preliminary haplotype construction for SNPs $79 \mathrm{~T}>\mathrm{G},+798 \mathrm{C}>\mathrm{T},+1762 \mathrm{~A}>\mathrm{G}$, $+2463 \mathrm{C}>\mathrm{T}$, and $+2731 \mathrm{~A}>\mathrm{G}$, yielded two major haplotypes of $\underline{G}_{79} \underline{T}_{798} \mathrm{~A}_{1762} \mathrm{C}_{2463} \underline{G}_{2731}$ (frequency 0.42) and $\mathrm{T}_{79} \mathrm{C}_{798} \underline{\mathrm{G}}_{1762} \underline{\mathrm{T}}_{2463} \mathrm{~A}_{2731}$ (frequency 0.41) (underlined allele denotes change from the published Btau_4.0 sequence NC_007304.4). Owing to the low number of individuals typed for all five markers $(n=$ 125), haplotype association analysis was not performed.

\section{Analysis of boTLR1 SNPs with clinical mastitis}

The three boTLR1 SNPs $-79 \mathrm{~T}>\mathrm{G},+1762 \mathrm{~A}>\mathrm{G}$ and $+2463 \mathrm{C}>\mathrm{T}$ were analysed in Holstein Friesian cows for association with $\mathrm{CM}$ and milk production traits. Analysis of the tagging SNP -79 T > G revealed the TG and GG genotypes associated with an increased rate of CM (0.75 and 0.70 cases/cow/year, respectively) compared with the TT genotype ( 0.40 cases/cow/year $)$ (Table 3). The association with CM rate was found to be significantly $(P<0.05)$ higher for the heterozygote (TG) population, the most abundant genotype, when compared with homozygote (TT) animals. The proportion of animals within each genotyped population having any episodes of CM during their first three lactations was highest in the GG genotype (70\%) compared with TT and TG genotypes (58\% and $60 \%$, respectively), although this was found not to be statistically significant. Analysis of the non-synonymous, transmembrane domain SNP; +1762A > G, showed AA and AG animals had higher rates of CM (0.69 and 0.66 cases/cow/year, respectively) compared with GG animals (0.38 cases/ cow/year), although these differences were not significantly different. Analysis of the SNP +2463 C > T located within the 3'UTR revealed that CC and CT animals had higher rates of CM (0.70 cases/cow/year) compared to TT animals (0.39 cases/cow/year). However, only the increase seen in the most abundant genotype, heterozygous CT cows, was shown to be statistically significant $(P<0.05)$.

\section{Association of boTLR1 SNPs with milk productivity traits}

Analysis of the productivity traits within the genotyped animals revealed that the TG and GG genotypes of the tagging SNP -79 $\mathrm{T}>\mathrm{G}$ associated significantly with lowered milk fat (TG $=P<0.05$, GG $=P<0.01)$ and protein (TG $=P<0.01, \mathrm{GG}=P<0.001)$ concentrations 


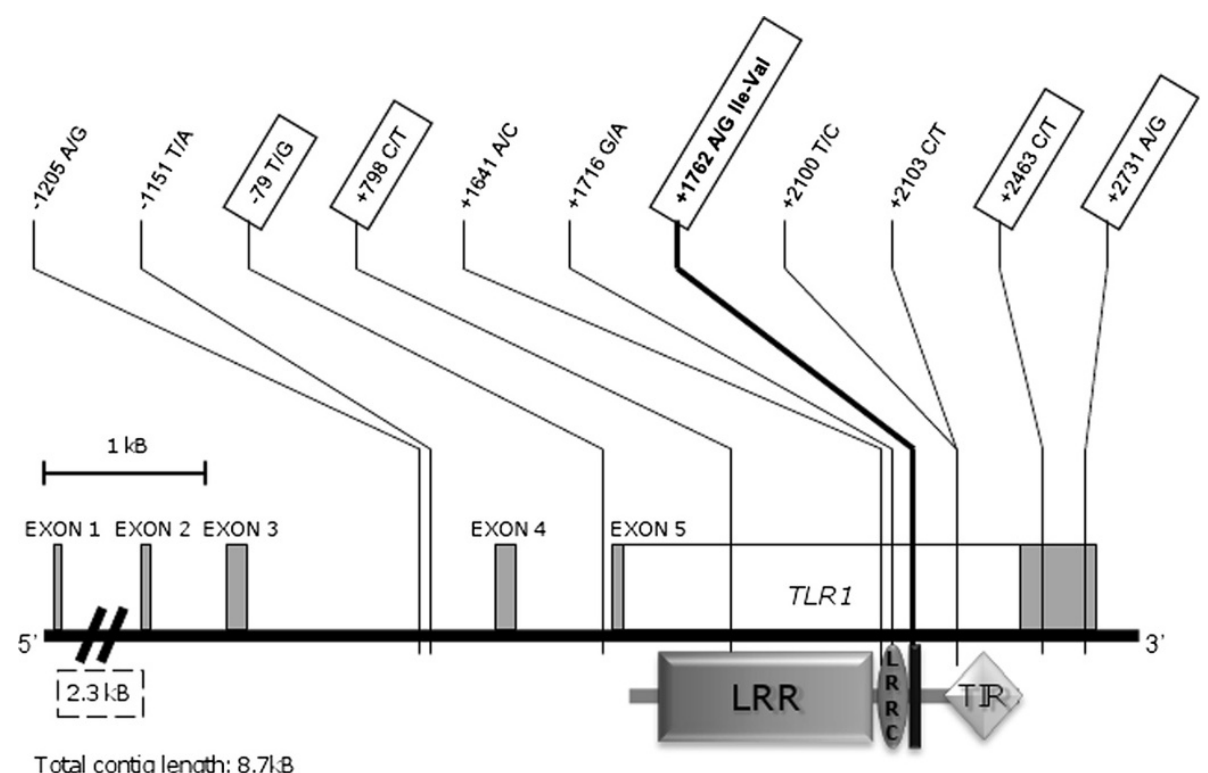

Figure 1 Schematic diagram showing the positions of identified SNPs within the bovine TLR1 gene. Open box represents coding exon $(\mathrm{CDS}=2379 \mathrm{bp})$, grey boxes represent non-coding untranslated exonic regions (UTR). A TLR1 protein domain architecture diagram, designed using web-based programmes [47,48], is illustrated below the CDS. The non-synonymous +1762A > G SNP (in bold), is located within the transmembrane domain (vertical black bar). LRR - leucine-rich repeat domains (19 in total), LRR C -leucine-rich repeat C terminal domain, TIR Toll-Interleukin 1-resistance domain. Sequence shown from Btau_4.0 sequence (NC_007304.4), bta6: 60355 k-60363 k. Boxed SNPs have been sequenced extensively for trait associations.

when compared to those observed in the TT genotype (Table 3). A similar trend was detected in the genotypes of the SNP +1762A > G; AA and AG genotypes associated with lower milk fat and protein concentrations; however these differences were not statistically significant. Analysis of genotypes within the SNP +2463 C >
$\mathrm{T}$ revealed that $\mathrm{CT}$ and $\mathrm{CC}$ genotypes produced milk with lower protein concentration $(P<0.05)$ when compared with the TT population. The same genotypes tended to show lower milk fat concentration, but these differences were not significant. No differences in either milk yield or mean SCC were detected between any of

Table 2 Genotype and allele frequencies including significance from Hardy-Weinberg equilibrium for boTLR1 SNPs selected for trait association.

\begin{tabular}{|c|c|c|c|c|c|c|}
\hline SNP & Genotype & $\mathrm{n}=$ & Genotype Frequency & HWE & Allele & Allele Frequency \\
\hline \multirow[t]{3}{*}{$-79 \mathrm{~T}>\mathrm{G}$} & $\pi$ & 53 & 0.34 & 0.831 & $\mathrm{~T}$ & 0.568 \\
\hline & TG & 71 & 0.46 & & G & 0.432 \\
\hline & GG & 32 & 0.20 & & & \\
\hline \multirow[t]{3}{*}{$+798 \mathrm{C}>\mathrm{T}^{1}$} & $\mathrm{CC}$ & 78 & 0.32 & 0.885 & $C$ & 0.543 \\
\hline & $\mathrm{CT}$ & 122 & 0.49 & & $T$ & 0.456 \\
\hline & $\pi$ & 46 & 0.19 & & & \\
\hline \multirow[t]{3}{*}{$+1762 A>G^{1}$} & $\mathrm{AA}$ & 33 & 0.26 & 0.326 & A & 0.495 \\
\hline & GA & 57 & 0.46 & & G & 0.505 \\
\hline & GG & 35 & 0.28 & & & \\
\hline \multirow[t]{3}{*}{$+2463 \mathrm{C}>\mathrm{T}$} & CC & 64 & 0.28 & 0.163 & C & 0.507 \\
\hline & $\mathrm{CT}$ & 102 & 0.46 & & $\mathrm{~T}$ & 0.493 \\
\hline & $\pi$ & 59 & 0.26 & & & \\
\hline \multirow[t]{3}{*}{$+2731 \mathrm{~A}>\mathrm{G}$} & $\mathrm{AA}$ & 77 & 0.33 & 0.611 & A & 0.546 \\
\hline & $A G$ & 110 & 0.48 & & G & 0.454 \\
\hline & GG & 45 & 0.19 & & & \\
\hline
\end{tabular}




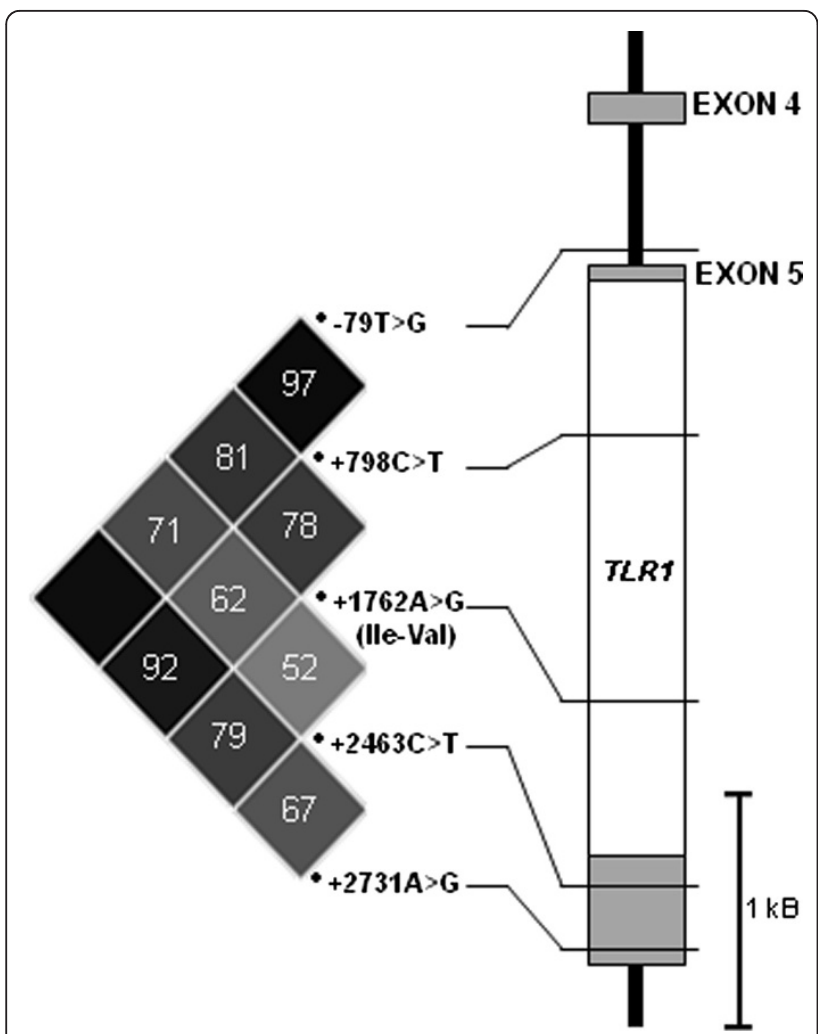

Figure 2 Linkage disequilibrium (LD) plot for five extensively genotyped SNPs in relation to the boTLR1 gene model. Open box represents boTLR1 coding exon, grey boxes represent noncoding untranslated (UTR) exonic regions. The non-synonymous amino acid change is shown in brackets below corresponding coding SNP. The graphical representation, generated by Haploview, of the $r^{2} L D$ relationship between each SNP is expressed on a grayscale gradient; where black - very high $L D\left(r^{2}=1.0\right)$ and white very low $L D(<0.1)$. The $r^{2}$ value for each pair-wise comparison is shown, where no value is indicated $r^{2}=1$.

the genotyped populations, for any of the SNPs described.

\section{Multiple comparisons}

Correlation coefficient analysis was performed revealing a weak positive correlation between CM and SCC (Pearson coefficient $=0.198$ ) and weak negative correlations between $\mathrm{CM}$ and milk fat and milk protein percentages (Pearson coefficient $=-0.2$ and -0.1 respectively). All significant associations between individual SNP genotypes and CM were found to survive adjustments for each factor using a General linear model (GLM).

\section{Q-PCR analysis of basal boTLR1 mRNA abundance}

Milk somatic cells from cows with representative boTLR1 -79 T > G SNP genotypes were assessed for differences in basal boTLR1 expression. All animals were of similar age and stage of lactation and none had any known health issues. Q-PCR assays were performed using RNA from five animals of each genotype. Cows with the GG genotype demonstrated lower boTLR1 mRNA abundance $(P<0.01)$ compared with either the TT or TG genotypes (Figure 3). Due to close homology and potential for co-expression, the abundance of boTLR6 mRNA was also measured and revealed no significant differences.

\section{Variation in immune responses to a TLR1 ligand}

Cells from twelve animals (four from each representative boTLR1 -79 T > G SNP genotype) were stimulated for up to $24 \mathrm{~h}$ with the ligand Pam3csk $4\left(\mathrm{PAM}_{3}\right)$, which has an affinity for TLR1/TLR2 heterodimers [49]. CXCL8 and IL- 6 mRNA abundance and CXCL8 and IL-6 production were used as markers for TLR1 stimulation. QPCR analysis indicated that animals with the GG genotype had lower levels of CXCL8 mRNA $4 \mathrm{~h}$ post-stimulation with $\mathrm{PAM}_{3}$ compared to equivalent samples from animals with either of the TT or TG genotypes (Figure 4). Samples from animals that were homozygous TT showed significantly greater $(P<0.05)$ CXCL8 mRNA abundance $4 \mathrm{~h}$ after stimulation with $\mathrm{PAM}_{3}$ at concentrations of 250 and $500 \mathrm{ng} / \mathrm{mL}$ when compared to GG homozygotes (Figure 4a). Homozygous TT animals tended to show greater $I L-6$ abundance $4 \mathrm{~h}$ after stimulation however no significant differences were detected between genotypes across all ligand concentrations (data not shown). A similar trend in CXCL8 and IL-6 data was observed from cells stimulated for $8 \mathrm{~h}$ (data not shown). Animals that were homozygous TT displayed significantly greater $(P<0.05) I L-6$ mRNA abundance 8 $\mathrm{h}$ after stimulation with $\mathrm{PAM}_{3}$ at $500 \mathrm{ng} / \mathrm{mL}$ when compared to GG homozygotes (data not shown).

The mRNA abundance of the anti-apoptotic factor $B c l 2 A 1$ was used as an additional marker to indicate differences in TLR1 stimulation. Following stimulation with $\mathrm{PAM}_{3}, \mathrm{Q}-\mathrm{PCR}$ analysis showed greater levels of Bcl2A1 mRNA in animals with the TT genotype compared to those with either the TG or GG genotypes (Figure 4b). Significantly $(P<0.05)$ greater levels of mRNA were detected in samples from animals with the TT genotype compared to those with the TG genotype following stimulation with $\mathrm{PAM}_{3}$ at $250 \mathrm{ng} / \mathrm{mL}$ and 500 $\mathrm{ng} / \mathrm{mL}$. In contrast, a statistically significant difference between the TT and GG genotypes was only detected following stimulation at the higher concentration.

Supernatants (24 h post-stimulation) were assayed for CXCL8 and IL- 6 production by ELISA. CXCL8 data showed a similar trend to those obtained by Q-PCR, with significantly $(P<0.05)$ lower levels of CXCL8 produced by cows with the GG genotype than those with the TT genotype following stimulation with $500 \mathrm{ng} / \mathrm{mL}$ $\mathrm{PAM}_{3}$ (Figure 5a). Individual variation was largest within those samples from TG heterozygotes, with 
Table 3 Analysis of boTLR1 SNP genotypes by CM and milk productivity traits over the first three lactations.

\begin{tabular}{|c|c|c|c|c|c|c|c|c|c|c|c|c|c|}
\hline SNP & Gen. & $\mathbf{n}=$ & $\begin{array}{l}\text { P\% with } \\
\mathrm{CM}^{1}\end{array}$ & $\begin{array}{l}\text { Mean CM } \\
\text { rate }^{2}\end{array}$ & $\begin{array}{l}P= \\
3\end{array}=$ & $\begin{array}{l}\text { Median } \\
\text { SCC }^{4}\end{array}$ & $\begin{array}{l}P= \\
3\end{array}=$ & $\begin{array}{l}\text { Mean } 305 \text { d milk } \\
\text { yield }^{4}\end{array}$ & $\begin{array}{l}P= \\
3\end{array}$ & $\begin{array}{l}\text { Mean milk } \\
\text { fat }(\%)^{4}\end{array}$ & $\begin{array}{l}P= \\
3\end{array}=$ & $\begin{array}{l}\text { Mean milk } \\
\text { protein }(\%)^{4}\end{array}$ & $P={ }^{3}$ \\
\hline \multirow[t]{3}{*}{$\begin{array}{l}\operatorname{tag}-79 \mathrm{~T} \\
>\mathrm{G}\end{array}$} & IT & $78^{*}$ & $58 \%$ & $\begin{array}{l}0.40( \pm \\
0.11)\end{array}$ & & $\begin{array}{l}1.96( \pm \\
0.63)\end{array}$ & & $7868( \pm 1181)$ & & $4.15( \pm 0.41)$ & & $3.28( \pm 0.19)$ & \\
\hline & $\mathrm{TG}$ & $122^{*}$ & $60 \%$ & $\begin{array}{l}0.75( \pm \\
0.18)\end{array}$ & $\begin{array}{l}< \\
0.05\end{array}$ & $\begin{array}{l}1.85( \pm \\
0.61)\end{array}$ & - & $8058( \pm 1139)$ & - & $4.02( \pm 0.38)$ & $\begin{array}{l}< \\
0.05\end{array}$ & $3.2( \pm 0.17)$ & $\begin{array}{l}< \\
0.01\end{array}$ \\
\hline & GG & $46^{*}$ & $70 \%$ & $\begin{array}{l}0.70( \pm \\
0.24)\end{array}$ & - & $\begin{array}{l}1.98( \pm \\
0.67)\end{array}$ & - & $7983( \pm 1273)$ & - & $3.89( \pm 0.41)$ & $\begin{array}{l}< \\
0.01\end{array}$ & $3.16( \pm 0.18)$ & $\begin{array}{l}< \\
0.001\end{array}$ \\
\hline \multirow[t]{3}{*}{$\begin{array}{l}+1762 \mathrm{~A} \\
>\mathrm{G}\end{array}$} & $\mathrm{AA}$ & 33 & $63 \%$ & $\begin{array}{l}0.69( \pm \\
0.27) \\
\end{array}$ & - & $\begin{array}{l}1.96( \pm \\
0.64)\end{array}$ & - & $8101( \pm 1106)$ & - & $3.95( \pm 0.41)$ & - & $3.19( \pm 0.18)$ & - \\
\hline & $\mathrm{GA}$ & 57 & $61 \%$ & $\begin{array}{l}0.66( \pm \\
0.18)\end{array}$ & - & $\begin{array}{l}1.89( \pm \\
0.69)\end{array}$ & - & $8067( \pm 1330)$ & - & $4.04( \pm 0.45)$ & - & $3.21( \pm 0.2)$ & - \\
\hline & $\mathrm{GG}$ & 35 & $59 \%$ & $\begin{array}{l}0.38( \pm \\
0.16)\end{array}$ & & $\begin{array}{l}1.90( \pm \\
0.62)\end{array}$ & & $8239( \pm 1185)$ & & $4.05( \pm 0.38)$ & & $3.25( \pm 0.16)$ & \\
\hline \multirow[t]{3}{*}{$\begin{array}{l}+2463 C \\
>T\end{array}$} & CC & 64 & $67 \%$ & $\begin{array}{l}0.70( \pm \\
0.24)\end{array}$ & - & $\begin{array}{l}1.95( \pm \\
0.66)\end{array}$ & - & $7841( \pm 1067)$ & - & $4.02( \pm 0.45)$ & - & $3.19( \pm 0.18)$ & $\begin{array}{l}< \\
0.05\end{array}$ \\
\hline & $C T$ & 102 & $61 \%$ & $\begin{array}{l}0.70( \pm \\
0.14) \\
\end{array}$ & $\begin{array}{l}< \\
0.05 \\
\end{array}$ & $\begin{array}{l}1.90( \pm \\
0.63)\end{array}$ & - & $8137( \pm 1206)$ & - & $3.98( \pm 0.45)$ & - & $3.18( \pm 0.2)$ & $\begin{array}{l}< \\
0.05 \\
\end{array}$ \\
\hline & II & 59 & $59 \%$ & $\begin{array}{l}0.39( \pm \\
0.11)\end{array}$ & & $\begin{array}{l}1.88( \pm \\
0.63)\end{array}$ & & $7940( \pm 1262)$ & & $4.13( \pm 0.38)$ & & $3.27( \pm 0.18)$ & \\
\hline
\end{tabular}

Abbreviations: Gen. = genotype, P\% = population percentage, CM = clinical mastitis, SCC = somatic cell count. * Numbers from tagged SNP +798 C $>$ T in Table 2. ${ }^{1}$ No significance was detected between genotypes by $\mathrm{Chi} \wedge 2$ odds ratio test. ${ }^{2}$ Mean $\pm 95 \%$ confidence interval given in column parentheses. ${ }^{3} P$ values analysed by ANOVA and Tukey's multiple comparisons, showing only results tested against the underlined (lower CM rate) genotype; - (dash) denotes no significance.

${ }^{4}$ Standard deviation from the mean given in column parentheses.

higher concentrations of $\mathrm{PAM}_{3}$ resulting in increased variability in CXCL8 production. IL-6 data showed significantly $(P<0.05)$ lower levels produced by cows with the GG genotype than the TT genotype following stimulation with $500 \mathrm{ng} / \mathrm{mL} \mathrm{PAM}_{3}$ (Figure 5b). Overall

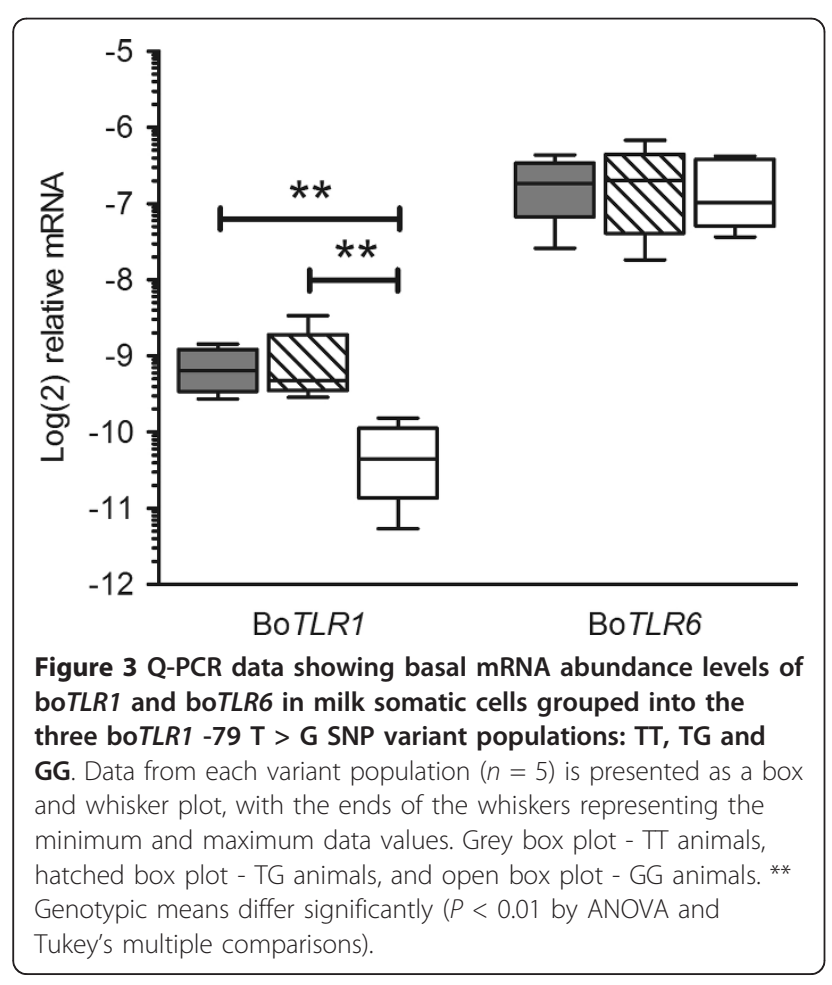

stimulation with TLR1 ligand across all concentrations did not increase cytokine production in GG variants. The TLR4 ligand LPS was used to assess if the detected variation in response to $\mathrm{PAM}_{3}$ reflected the ability of the cell populations to respond to any ligand. The response to LPS was variable across all genotypes and did not segregate by the defined genotypes (Additional file 2).

\section{Discussion}

In this study we analysed five SNPs within exonic and non-exonic regions of boTLR1 for susceptibility to CM. We identified significant associations between the tagging SNP $-79 \mathrm{~T}>\mathrm{G}$, and the 3'UTR SNP $+2463 \mathrm{C}>\mathrm{T}$ and susceptibility to CM. Rates of CM for genotypes $-79 \mathrm{TT}$ and $+2463 \mathrm{TT}$ were much lower in comparison to the homozygous genotypes ( $-79 \mathrm{GG}$ and $+2463 \mathrm{CC}$ ) and significantly lower than their respective heterozygous genotypes. The CM rate differences observed between defined genotypes can have a significant impact on both herd welfare and farm expenditure. For example, the -79 TT animals recorded on average $40 \mathrm{CM}$ cases per 100 cows per year, below the historic national average for England and Wales, which has been estimated at 47 cases [1]. GG and TG animals recorded 70 and 75 cases respectively, a substantial increase from the national average. As a simple economic evaluation, if estimated average costs for a clinical case are $£ 175$ [50] potential losses per 100 cows when compared to TT animals equate to $£ 6125$ and $£ 5250$ for TG and GG animals respectively. 


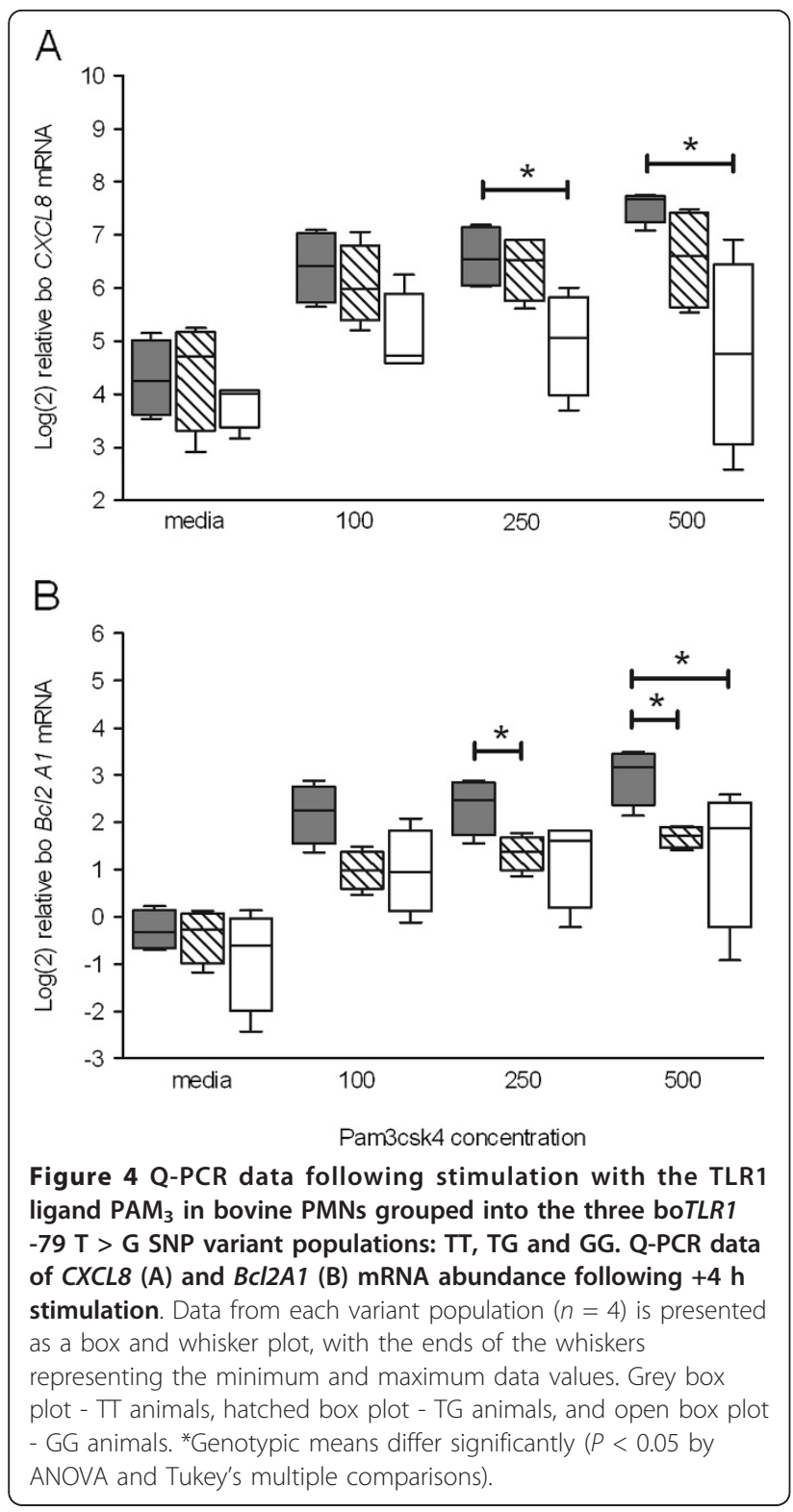

Dairy cows are subjected to intense selection pressures for higher milk yields and reduced SCC that may unintentionally be detrimental to CM incidence [5]. However, in this study, no significant differences were observed between boTLR1 SNPs for mean $305 \mathrm{~d}$ milk yields or SCC. This contradicts a study of 208 Chinese Holsteins, in which the non-synonymous SNP $+1762 \mathrm{~A}>$ $\mathrm{G}$ associated with highly significant differences in milk SCC. Animals with an AA (Isoleucine) at this position had lower SCC and were classed as more resistant to mastitis [36]. In contrast, our results suggest the GG (Valine) at this location is the more favourable genotype in terms of having a lower CM incidence in comparison to AA. Although this discrepancy may reflect breed and herd variation, it may also demonstrate the dichotomy

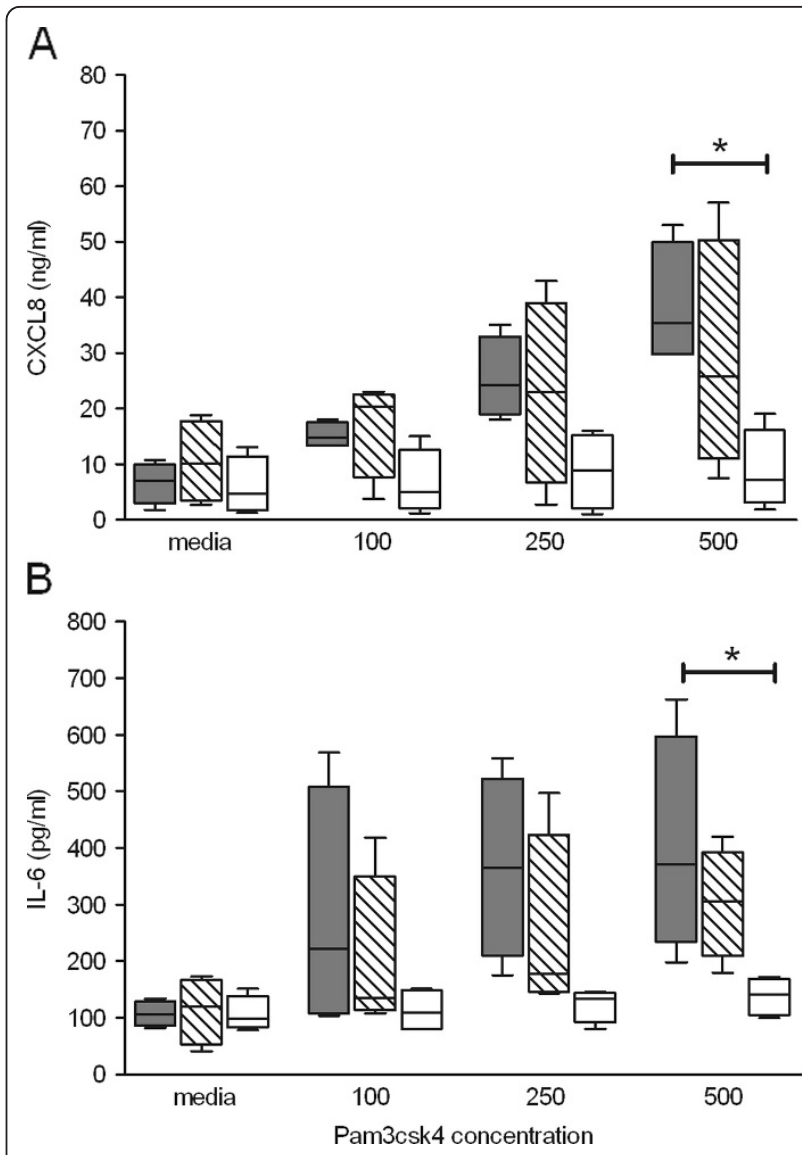

Figure 5 ELISA data following stimulation with the TLR1 ligand $\mathrm{PAM}_{3}$ in bovine PMNs grouped into the three boTLR1 -79 T > G SNP variant populations: TT, TG and GG. ELISA data of CXCL8 (A) and IL-6 (B) production following $+24 \mathrm{~h}$ stimulation Data from each variant population $(n=4)$ is presented as a box and whisker plot, with the ends of the whiskers representing the minimum and maximum data values. Grey box plot - $\Pi$ animals, hatched box plot - TG animals, and open box plot - GG animals. * Genotypic means differ significantly $(P<0.05$ by ANOVA and Tukey's multiple comparisons).

that the surrogate measure of mastitis is also the presence of the effector cell which can at times eliminate infection in the absence of overt clinical signs.

All boTLR1 SNP genotypes associated with a lowered rate of CM display significantly greater milk fat and protein concentrations when compared to the other two genotypes. It is unclear whether a functional association exists between milk fat and protein concentrations and mastitis susceptibility. Interestingly the casein gene cluster is located $\sim 28 \mathrm{Mb}$ from the TLR6-TLR1-TLR10 gene cluster on bta6 [51]. Protein and fat contents are financially rewarded milk qualities and breeding for these factors could influence boTLR1 genotypes.

In addition to being one of the first studies to examine association between boTLR1 SNPs and CM incidence, we further demonstrate evidence of variable receptor 
responses between the defined genotypes. In this study animals segregated by $-79 \mathrm{~T}>\mathrm{G}$ SNP genotypes exhibited significantly lower boTLR1 expression in GG animals when compared with TT or TG. This difference, which appeared to be specific for boTLR1 as it was not seen for boTLR6 a paralogue of boTLR1, may indicate interference with transcription. Although more variable, intermediate basal expression levels observed in TG cows suggests that the presence of a $\mathrm{T}$ allele is compensating for the lowered expression originating from the $G$ allele. Preliminary analysis for causal mutations using the programme MOTIF [52] highlighted the $-79 \mathrm{~T}>\mathrm{G}$ SNP as part of an Octamer-1 (Oct-1) motif. Oct-1 is thought to work closely with AP-1 and GATA-1 as important regulatory elements for TLR expression [53]. However the motif was only identified with the $T$ variant (threshold $>80 \%$ ), and was absent in those with the $\mathrm{G}$ substitution. Although this is an attractive hypothesis it is also possible that the SNP may simply be a marker for other unidentified causal mutations.

Currently there are no boTLR1 antibodies available to directly compare levels of protein expression. To ascertain the functional consequence of potentially reduced boTLR1 expression, production of cytokines known to be induced by TLR1 was determined from cells stimulated with the TLR1 ligand $\mathrm{PAM}_{3}$. Our study demonstrated genotype-specific variation in cytokine responses of bovine PMN to $\mathrm{PAM}_{3}$. Across all time points and ligand concentrations analysed, $\mathrm{PAM}_{3}$ stimulation of cells from animals segregated by tagging $-79 \mathrm{~T}>\mathrm{G}$ SNP genotypes revealed lower levels of CXCL8 and IL- 6 mRNA and protein from those of a GG genotype and consistently high CXCL8 and IL-6 response from those with TT genotypes. The output of cytokines from cells from the TG animals was the most variable. The NF $\kappa \mathrm{B}-$ transcribed gene [54] encoding the pro-survival protein $B c l 2 A 1$, which is up-regulated in neutrophils following stimulation with TLR ligands including $\mathrm{PAM}_{3}$ [55], was used as an additional marker of effective boTLR1 stimulation. Significantly greater levels of the $B c l 2 A 1$ transcript were detected in animals with the TT genotype compared to those with the TG or GG genotypes. All genotypes were also stimulated with LPS, and no differences were detected in levels of CXCL8 or IL6. This further indicates that differences observed following stimulation with $\mathrm{PAM}_{3}$ were influenced by variation in the response via boTLR1.

PMNs contain a high proportion of neutrophils, whose primary role is the phagocytosis of microbes to contain and eliminate infection. However stimulated neutrophil TLRs further induce the neutrophil to synthesise cytokines that influence their own activity and survival, recruit additional immune cells and modulate the immune response [56-59]. The greater expression of $B c l 2 A 1$ in animals with the TT genotype may promote PMN survival to complement the increased cytokine output. Reduced boTLR1 stimulation by pathogens in GG cows may equate to a dampened inflammatory response thus enabling establishment and persistence of infection. In terms of influence upon mastitis susceptibility, GG cows have a higher CM rate than TT cows; however heterozygous TG cows have a similar rate to GG cows, despite expressing boTLR1 at a similar level to a TT cow. TG animals showed intermediary cytokine responses to TLR1 ligand, and like GG animals, lower expression of Bcl2A1. This may suggest that differences in boTLR1 transcript levels alone may not account for the variation in receptor response, and/or that post-transcriptional control of translation may also be affected by the cumulative presence of SNPs. The animals used for the functional assays conform to observed haplotypes: $\mathrm{TT}=\mathrm{T}_{79} \mathrm{C}_{798} \mathrm{G}_{1762} \mathrm{~T}_{2463} \mathrm{~A}_{2731}$ and $\mathrm{GG}=\mathrm{G}_{79} \mathrm{~T}_{798} \mathrm{~A}_{1762} \mathrm{C}_{2463} \mathrm{G}_{2731}$; with $\mathrm{TG}$ animals heterozygous for each SNP. In terms of the likelihood of being causative of a variable TLR1 response, the non-synonymous SNP +1762 Iso > Val is an unlikely candidate. Both Isoleucine and Valine are non-polar branched amino acids with hydrophobic properties, and so a substitution within the transmembrane domain should not impact the tertiary structure; although further targeted structure/function studies are required to verify this. Furthermore, influence of polymorphisms within TLRrelated or target genes such as TLR2 and CXCL8 should be considered.

In conclusion the findings presented here demonstrate an association between SNPs, common to boTLR1, and CM susceptibility. Furthermore, we present evidence that some of these SNPs underpin functional variation in boTLR1. A rapid immune response, conferred by the favourable boTLR1 SNP -79 TT variant, could reduce detrimental clinical manifestations of diseases via an efficient yet controlled influx of inflammatory cells to neutralise pathogens and control infection. The complexity of mastitis infection suggests a polygenic and multi-factorial immune response comprising many different proteins which will in turn interact with one another. The ability to detect significant associations with CM for a single gene indicates the importance of boTLR1 related responses in the control of bacterial disease in cattle. A bovine population with impaired boTLR1 expression may also be more susceptible to other diseases and health issues. Preliminary evidence for this comes from our study where it was observed that animals with the GG variant seemed to be prematurely culled compared to other populations.

The potential of SNPs within boTLR1 to act as genetic markers for altered susceptibility to mastitis warrants further investigation. The favourable linkage of lowered 
$\mathrm{CM}$ with increased milk fat and protein concentrations in the boTLR1 variants demonstrated here indicates selection for lowered CM using these markers would not be detrimental to milk quality, as has been previously suggested in studies linking SNPs with increased $\mathrm{SCC}$ as a marker for CM susceptibility.

\section{Additional material}

Additional file 1: Primers used for PCR amplification of boTLR1 genomic regions, RFLP PCR digests, and quantitative PCR (QPCR) assays.

Additional file 2: Table to show expression levels of $C X C L 8$ and $B C / 2$ $A 1$ and CXCL8 and IL-6 production levels following PMN stimulation with LPS

\section{Acknowledgements}

The authors wish to acknowledge the help of R Parsons (Institute for Animal Health/IAH Compton) and A Bowen (IAH Compton) for contributing valuable tools to this project. We also thank the staff at Mayfield Dairy, IAH Compton, UK, for animal handling and sampling assistance. This study is part of a PhD project funded through a Doctoral Training Partnership from the Biotechnology and Biological Sciences Research Council administered through the IAH.

\section{Author details}

'Bovine Genomics Group, Institute for Animal Health, Compton, Berkshire, RG20 7NN, UK. ${ }^{2}$ The School of Veterinary Medicine and Science, The University of Nottingham, Sutton Bonington Campus, Sutton Bonington, Leicestershire, LE12 5RD, UK.

\section{Authors' contributions}

Conceived and designed the experiments: CDR, SW, JAL, TJC. Performed the experiments: CDR. Analysis and discussion of data: CDR, SW, JAL, TJC. Wrote the manuscript: CDR. Edited the manuscript: SW, JAL, TJC. All authors read and approved the final manuscript.

\section{Competing interests}

The authors declare that they have no competing interests.

Received: 20 December 2011 Accepted: 14 March 2012

Published: 14 March 2012

\section{References}

1. Bradley AJ, Leach KA, Breen JE, Green LE, Green MJ: Survey of the incidence and aetiology of mastitis on dairy farms in England and Wales. Vet Rec 2007, 160:253-257.

2. Leigh JA: Streptococcus uberis: a permanent barrier to the control of bovine mastitis? Vet J 1999, 157:225-238.

3. Rupp R, Boichard D: Genetic parameters for clinical mastitis, somatic cell score, production, udder type traits, and milking ease in first lactation Holsteins. J Dairy Sci 1999, 82:2198-2204.

4. Barkema HW, Schukken YH, Lam TJ, Beiboer ML, Wilmink H, Benedictus G, Brand A: Incidence of clinical mastitis in dairy herds grouped in three categories by bulk milk somatic cell counts. J Dairy Sci 1998, 81:411-419.

5. Suriyasathaporn $W$, Schukken $Y H$, Nielen $M$, Brand A: Low somatic cell count: a risk factor for subsequent clinical mastitis in a dairy herd. $J$ Dairy Sci 2000, 83:1248-1255.

6. Skelding A, Schenkel FS, Sharma BS, Verschoor C, Pant S, Biggar G, Boermans $\mathrm{H}$, Karrow N: Identification of single nucleotide polymorphisms in the bovine interleukin-12 and interleukin-23 receptor genes and their associations with health and production traits in Holstein cows. J Dairy Sci 2010, 93:4860-4871.
7. Beecher C, Daly M, Childs S, Berry DP, Magee DA, McCarthy TV, Giblin L: Polymorphisms in bovine immune genes and their associations with somatic cell count and milk production in dairy cattle. BMC Genet 2010, 11:99.

8. Chen R, Yang Z, Ji D, Mao Y, Chen Y, Li Y, Wu H, Wang X, Chang L: Polymorphisms of the IL8 gene correlate with milking traits, SCS and mRNA level in Chinese Holstein. Mol Biol Rep 2011, 36:4083-4088.

9. Sharma BS, Leyva I, Schenkel F, Karrow NA: Association of toll-like receptor 4 polymorphisms with somatic cell score and lactation persistency in Holstein bulls. J Dairy Sci 2006, 89:3626-3635.

10. Oviedo-Boyso J, Valdez-Alarcon JJ, Cajero-Juarez M, Ochoa-Zarzosa A, Lopez-Meza JE, Bravo-Patino A, Baizabal-Aguirre VM: Innate immune response of bovine mammary gland to pathogenic bacteria responsible for mastitis. J Infect 2007, 54:399-409.

11. Kawai T, Akira S: Pathogen recognition with Toll-like receptors. Curr Opin Immunol 2005, 17:338-344.

12. Werling $D$, Jungi TW: TOLL-like receptors linking innate and adaptive immune response. Vet Immunol Immunopathol 2003, 91:1-12

13. Ibeagha-Awemu EM, Lee JW, Ibeagha AE, Bannerman DD, Paape MJ, Zhao X: Bacterial lipopolysaccharide induces increased expression of tolllike receptor (TLR) 4 and downstream TLR signaling molecules in bovine mammary epithelial cells. Vet Res 2008, 39:11.

14. De Schepper S, De Ketelaere A, Bannerman DD, Paape MJ, Peelman L, Burvenich C: The toll-like receptor-4 (TLR-4) pathway and its possible role in the pathogenesis of Escherichia coli mastitis in dairy cattle. Vet Res 2008, 39:5

15. Goldammer T, Zerbe H, Molenaar A, Schuberth HJ, Brunner RM, Kata SR, Seyfert HM: Mastitis increases mammary mRNA abundance of betadefensin 5, toll-like-receptor 2 (TLR2), and TLR4 but not TLR9 in cattle. Clin Diagn Lab Immunol 2004, 11:174-185.

16. Yang W, Zerbe H, Petzl W, Brunner RM, Gunther J, Draing C, von Aulock S, Schuberth HJ, Seyfert HM: Bovine TLR2 and TLR4 properly transduce signals from Staphylococcus aureus and E. coli, but $S$. aureus fails to both activate NF-kappaB in mammary epithelial cells and to quickly induce TNFalpha and interleukin-8 (CXCL8) expression in the udder. Mol Immunol 2008, 45:1385-1397.

17. McGuire K, Jones M, Werling D, Williams JL, Glass EJ, Jann O: Radiation hybrid mapping of all 10 characterized bovine Toll-like receptors. Anim Genet 2006, 37:47-50

18. Menzies M, Ingham A: Identification and expression of Toll-like receptors 1-10 in selected bovine and ovine tissues. Vet Immunol Immunopathol 2006, 109:23-30.

19. Farhat K, Sauter KS, Brcic M, Frey J, Ulmer AJ, Jungi TW: The response of HEK293 cells transfected with bovine TLR2 to established pathogenassociated molecular patterns and to bacteria causing mastitis in cattle. Vet Immunol Immunopathol 2008, 125:326-336.

20. Lee JW, Bannerman DD, Paape MJ, Huang MK, Zhao X: Characterization of cytokine expression in milk somatic cells during intramammary infections with Escherichia coli or Staphylococcus aureus by real-time PCR. Vet Res 2006, 37:219-229.

21. Schroder NW, Schumann RR: Single nucleotide polymorphisms of Toll-like receptors and susceptibility to infectious disease. Lancet Infect Dis 2005 , 5:156-164

22. Mockenhaupt FP, Cramer JP, Hamann L, Stegemann MS, Eckert J, Oh NR, Otchwemah RN, Dietz E, Ehrhardt S, Schroder NW, Bienzle U, Schumann RR: Toll-like receptor (TLR) polymorphisms in African children: Common TLR4 variants predispose to severe malaria. Proc Natl Acad Sci USA 2006, 103:177-182.

23. Misch EA, Hawn TR: Toll-like receptor polymorphisms and susceptibility to human disease. Clin Sci (Lond) 2008, 114:347-360.

24. Misch EA, Macdonald M, Ranjit C, Sapkota BR, Wells RD, Siddiqui MR, Kaplan G, Hawn TR: Human TLR1 deficiency is associated with impaired mycobacterial signaling and protection from leprosy reversal reaction. PLoS Negl Trop Dis 2008, 2:e231.

25. Hawn TR, Misch EA, Dunstan SJ, Thwaites GE, Lan NT, Quy HT, Chau TT, Rodrigues S, Nachman A, Janer M, Hien TT, Farrar JJ, Aderem A: A common human TLR1 polymorphism regulates the innate immune response to lipopeptides. Eur J Immunol 2007, 37:2280-2289. 
26. Takeuchi O, Sato S, Horiuchi T, Hoshino K, Takeda K, Dong Z, Modlin RL, Akira S: Cutting edge: role of Toll-like receptor 1 in mediating immune response to microbial lipoproteins. J Immunol 2002, 169:10-14.

27. Omueti KO, Beyer JM, Johnson CM, Lyle EA, Tapping Rl: Domain exchange between human toll-like receptors 1 and 6 reveals a region required for lipopeptide discrimination. J Biol Chem 2005, 280:36616-36625.

28. Babu MM, Priya ML, Selvan AT, Madera M, Gough J, Aravind L, Sankaran K: A database of bacterial lipoproteins (DOLOP) with functional assignments to predicted lipoproteins. J Bacteriol 2006, 188:2761-2773.

29. Werling D, Jann OC, Offord V, Glass EJ, Coffey TJ: Variation matters: TLR structure and species-specific pathogen recognition. Trends Immunol 2009, 30:124-130.

30. Guan Y, Ranoa DR, Jiang S, Mutha SK, Li X, Baudry J, Tapping Rl: Human TLRs 10 and 1 share common mechanisms of innate immune sensing but not signaling. J Immunol 2010, 184:5094-5103.

31. Opsal MA, Vage DI, Hayes B, Berget I, Lien S: Genomic organization and transcript profiling of the bovine toll-like receptor gene cluster TLR6TLR1-TLR10. Gene 2006, 384:45-50.

32. Ogorevc J, Kunej T, Razpet A, Dovc P: Database of cattle candidate genes and genetic markers for milk production and mastitis. Anim Genet 2009, 40:832-851.

33. Klungland $H$, Sabry A, Heringstad B, Olsen HG, Gomez-Raya L, Vage DI, Olsaker I, Odegard J, Klemetsdal G, Schulman N, Vilkki J, Ruane J, Aasland M, Rønningen K, Lien S: Quantitative trait loci affecting clinical mastitis and somatic cell count in dairy cattle. Mamm Genome 2001, 12:837-842.

34. Jann OC, King A, Corrales NL, Anderson SI, Jensen K, Ait-Ali T, Tang H, Wu C, Cockett NE, Archibald AL, Glass EJ: Comparative genomics of Tolllike receptor signalling in five species. BMC Genomics 2009, 10:216.

35. Seabury CM, Cargill EJ, Womack JE: Sequence variability and protein domain architectures for bovine Toll-like receptors 1, 5, and 10. Genomics 2007, 90:502-515.

36. Li C, Shi W, Chu MX, An Y, Chen H, Di R, Fang L: Polymorphisms of TLR gene and their relationship with somatic cell Score in Holstein cows. Sci Agric Sin 2009, 42:2118-2125

37. The National Milk Records. [http://www.nmr.co.uk].

38. Murphy MA, Shariflou MR, Moran C: High quality genomic DNA extraction from large milk samples. J Dairy Res 2002, 69:645-649.

39. Rozen S, Skaletsky H: Primer3 on the WWW for general users and for biologist programmers. Methods Mol Biol 2000, 132:365-386.

40. Barrett JC, Fry B, Maller J, Daly MJ: Haploview: analysis and visualization of LD and haplotype maps. Bioinformatics 2005, 21:263-265.

41. Collins RA, Howard CJ, Duggan SE, Werling D: Bovine interleukin-12 and modulation of IFNgamma production. Vet Immunol Immunopathol 1999, 68:193-207.

42. Widdison S, Watson M, Piercy J, Howard C, Coffey TJ: Granulocyte chemotactic properties of M. tuberculosis versus M. bovis-infected bovine alveolar macrophages. Mol Immunol 2008, 45:740-749.

43. Widdison S, Watson M, Coffey TJ: Early response of bovine alveolar macrophages to infection with live and heat-killed Mycobacterium bovis. Dev Comp Immunol 2011, 35:580-591.

44. Kwong LS, Hope JC, Thom ML, Sopp P, Duggan S, Bembridge GP, Howard CJ: Development of an ELISA for bovine IL-10. Vet Immunol Immunopathol 2002, 85:213-223.

45. Farhat K, Riekenberg S, Jung G, Wiesmuller KH, Jungi TW, Ulmer AJ: Identification of full length bovine TLR1 and functional characterization of lipopeptide recognition by bovine TLR2/1 heterodimer. Vet Res 2010, 41:34.

46. National Center for Biotechnology Information: SNP Database. [http:// www.ncbi.n/m.nih.gov/projects/SNP].

47. SMART: Simple Modular Architecture Research Tool. [http://smart.emblheidelberg.de/].

48. Leucine-Rich Repeat Finder (LRRfinder) web-based tool. [http://www. Irrfinder.com/].

49. Jin MS, Kim SE, Heo JY, Lee ME, Kim HM, Paik SG, Lee H, Lee JO: Crystal structure of the TLR1-TLR2 heterodimer induced by binding of a triacylated lipopeptide. Cell 2007, 130:1071-1082.

50. Kossaibati MA: The costs of clinical mastitis in UK dairy herds. Cattle Practice 2000, 8:323-328.

51. Threadgill DW, Womack JE: Genomic analysis of the major bovine milk protein genes. Nucleic Acids Res 1990, 18:6935-6942.
52. Motif: Searching DNA/Protein Sequence Motifs. [http://motif.genome.jp].

53. Roger T, Miconnet I, Schiesser AL, Kai H, Miyake K, Calandra T: Critical role for Ets, AP-1 and GATA-like transcription factors in regulating mouse Toll-like receptor 4 (TIr4) gene expression. Biochem J 2005, 387:355-365.

54. Liang $Y$, Zhou $Y$, Shen P: NF-kappaB and its regulation on the immune system. Cell Mol Immunol 2004, 1:343-350.

55. Francois S, El Benna J, Dang PM, Pedruzzi E, Gougerot-Pocidalo MA, Elbim C: Inhibition of neutrophil apoptosis by TLR agonists in whole blood: involvement of the phosphoinositide 3-kinase/Akt and NFkappaB signaling pathways, leading to increased levels of $\mathrm{Mcl}-1, \mathrm{~A} 1$, and phosphorylated Bad. J Immunol 2005, 174:3633-3642.

56. Hayashi F, Means TK, Luster AD: Toll-like receptors stimulate human neutrophil function. Blood 2003, 102:2660-2669.

57. Kobayashi Y: The role of chemokines in neutrophil biology. Front Biosci 2008, 13:2400-2407.

58. Parker LC, Whyte MK, Dower SK, Sabroe I: The expression and roles of Toll-like receptors in the biology of the human neutrophil. J Leukoc Biol 2005, 77:886-892.

59. Paape MJ, Bannerman DD, Zhao X, Lee JW: The bovine neutrophil: Structure and function in blood and milk. Vet Res 2003, 34:597-627.

doi:10.1186/1297-9716-43-17

Cite this article as: Russell et al:: Identification of single nucleotide polymorphisms in the bovine Toll-like receptor 1 gene and association with health traits in cattle. Veterinary Research 2012 43:17.

\section{Submit your next manuscript to BioMed Central and take full advantage of:}

- Convenient online submission

- Thorough peer review

- No space constraints or color figure charges

- Immediate publication on acceptance

- Inclusion in PubMed, CAS, Scopus and Google Scholar

- Research which is freely available for redistribution

Submit your manuscript at www.biomedcentral.com/submit
Ciomed Central 